\title{
IMPLEMENT APPLICATION OF TAGUCHI METHOD FOR ANALYZING THE QUALITY CONTROL OF CRUDE PALM OIL PRODUCTION
}

\author{
Haniza1, Sutrisno $^{2}$, Andre Hasudungan Lubis ${ }^{3}$, Solly Aryza ${ }^{4}$ \\ 1,2, ${ }^{3}$ Faculty of Engineering, Universitas Medan Area, Indonesia \\ ${ }^{4}$ Universitas Pembangunan Panca Budi, Indonesia
}

\begin{abstract}
A quality control towards the production of Crude Palm Oil (CPO) production is a prominent instance to be held by companies. Through Taguchi method, several steps are conducted start with the selection of factors that affect the quality of $\mathrm{CPO}$ and factor level values which then become the basis in the selection of orthogonal matrices. Based on the result of the research, it is found that the factors that significantly influence the quality of CPO are boiling pressure, boiling temperature and clarification unit temperature. After applying the optimal combination of settings based on the Taguchi method, the overall proportion of overall defects decreased by $10.42 \%$.
\end{abstract}

Keywords: CPO Quality Control, Taguchi Method, Frequency of Defects.

\section{INTRODUCTION:}

The term of quality is broadly used in different fields. Furthermore, in the points of companies growth, product quality and services is the important role to be preserved by companies. Quality is one of the main factors to the consumers in choosing and determining the product to be used [1]. As example, the companies which are operating the production of Crude Palm Oil (CPO) should improve the resulting product while the emergence of competition among them. The Quality control is conducted starts from the process of input information or raw materials from the marketing, processed in the factory (phase transformation), then eventually sent to the customer [2][3]. Even quality control is also done after the sale [4].

As the one of CPO production company, PT. Perkebunan Nusantara II PKS Pagar Merbau still resulting vary product and often do not meet the company's quality or quality standard specifications. In the other hand, the most determined factors that influencing the quality of CPO is Free Fatty Acid (FFA) content. The specifications that have been determined by the company are FFA content $(3.0-4,5) \%$, M content $(0,10-0,35) \%$ and level of I $(0,01-0,02) \%$. As can be seen in Table 1 , there is a problem of quality control on product quality produced by the company is important and requires a more in-depth study.

Table 1: The Deviation of CPO data from Quality Standards.

\begin{tabular}{|c|c|c|c|c|c|c|}
\hline \multirow{3}{*}{ No. } & \multirow{3}{*}{ Date } & \multirow{3}{*}{$\begin{array}{c}\text { Total } \\
\text { Samples }\end{array}$} & \multicolumn{4}{|c|}{ Factors } \\
\hline & & & \multirow{2}{*}{$\begin{array}{c}\text { FFA content } \\
(3,0-4,5) \%\end{array}$} & \multirow{2}{*}{$\begin{array}{c}\text { M content } \\
(0,10-0,35) \%\end{array}$} & \multirow{2}{*}{$\begin{array}{c}\text { level of I } \\
(0,01-0,02) \%\end{array}$} & \multirow{2}{*}{$\begin{array}{c}\text { Number of } \\
\text { deviant results }\end{array}$} \\
\hline & & & & & & \\
\hline 1 & 01-Feb-16 & 12 & 3 & 2 & - & 5 \\
\hline 2 & 03-Feb-16 & 12 & 5 & 4 & 1 & 10 \\
\hline 3 & 05-Feb-16 & 12 & 6 & 2 & - & 8 \\
\hline 4 & 07-Feb-16 & 12 & 3 & 3 & - & 6 \\
\hline 5 & 09-Feb-16 & 12 & 4 & 2 & 2 & 8 \\
\hline
\end{tabular}

Here, an effort has been made to overcome these problems in identifying the factors by using Taguchi method. This method developed by Taguchi and Konishi and used for improving the quality of goods manufactured (manufacturing process development) [5]. The Taguchi method is a principled design method of quality improvement by minimizing the effects of variation without eliminating the cause. This can be obtained through product optimization and process design to make performance immune to various causes of variation of a process called parameter design [6].

There are two main measuring tools in the Taguchi design method, namely the control and noise factors. To obtain an optimum results of the process, Taguchi Method involves the identification of proper 
control factors. Moreover, this method also employs the Orthogonal Arrays (OA) to conduct a set of experiments that will be used to analyze the data and predict the quality of components produced.

\section{TAGUCHI METHOD:}

There are three simple and fundamental concepts to produce robust performance in accordance to Taguchi method, namely: quality robustness, target oriented quality, and quality loss function. The quality robustness is related to instance of products durability to environmental factors, then target oriented quality is an effort to minimizing deviations from a target, and quality loss function examines the measurement of losses of the entire system.

The function of the loss to the product arises from the deviation of product specifications from the established targets, ultimately losses are borne by the community (producers and consumers) during the use of the product. Taguchi uses a quality deviation function to measure loss due to functional variation, minimizing a product's performance deviation from its target value will improve product quality [7]. Thus, the smaller the functional variation, the smaller the losses are borne by society, which means the higher the quality of the product. There are three classification of quadratic functions according to Taguchi in determining the quality characteristics, namely the loss function Nominal is the best, Smaller the better, and Larger the better.

Taguchi method also OA matrix table to be performed in the experiments based on the number of degrees of freedom from all the factors involved in the experiment. Degree of freedom factor is obtained from the number of factor levels minus one. The total number of degrees of freedom of all these factors indicates the minimum number of rows that used to the orthogonal matrix.

\section{METHODOLOGY:}

Before analyzing the data, an interview towards the employees of company is conducted to sought the control factors that affect the quality of CPO. The result stated that boiling temperature, pressure on boiling and temperature in the clarification unit are deterimine the CPO quality. Based on the understanding of the nature of relationships between factors in the Taguchi concept, the relationship between factors or variables of theoretical framework of the study can be arranged as in Figure 1.

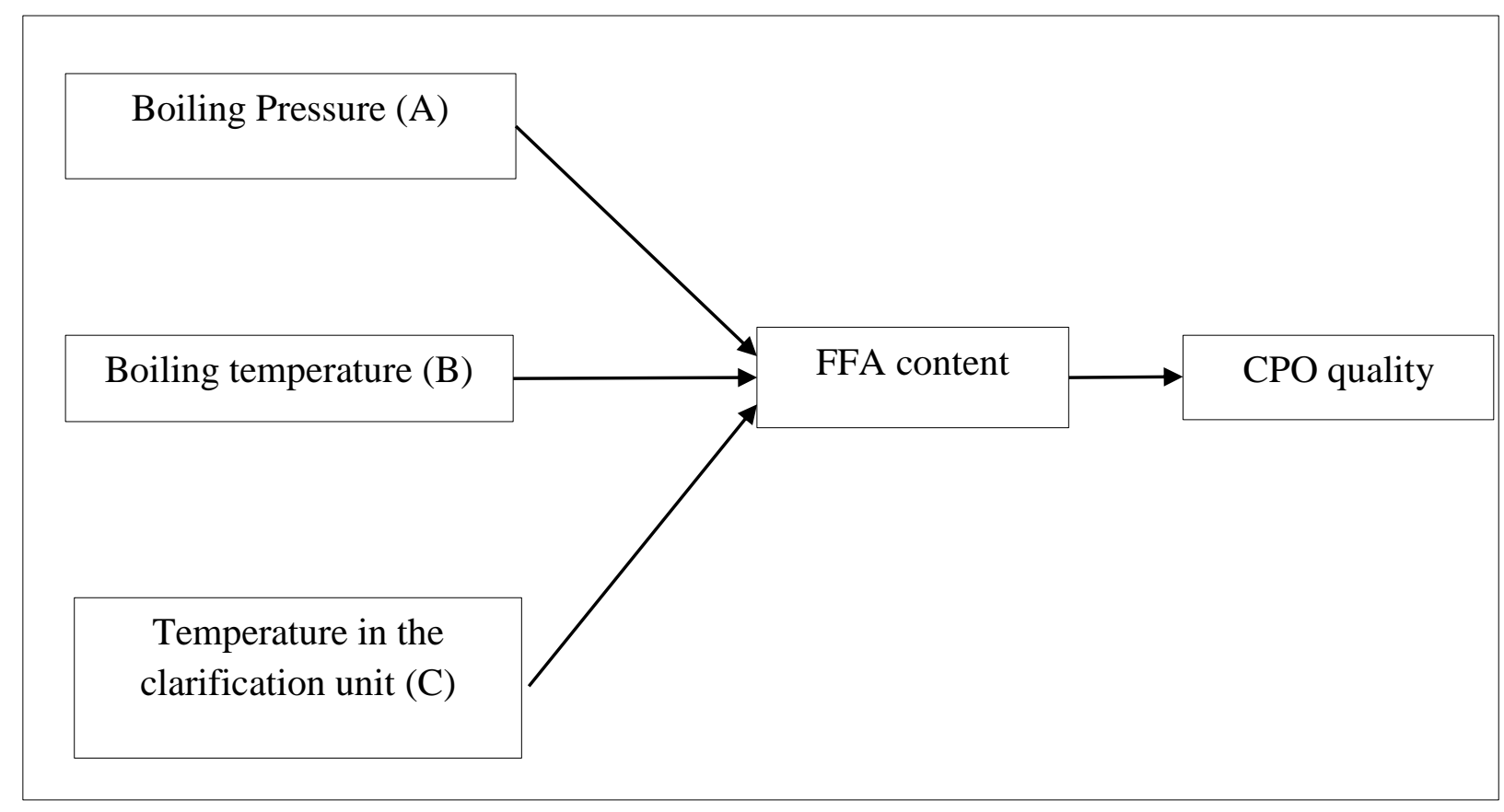

Figure 1: Theoritical Framework

As an experiment research, this study determines boiling temperature, boiling pressure, and temperature in the clarification unit as the independent variable. Additionally, CPO production data act as the dependent variable. This research was conducted at PT. Perkebunan Nusantara II Palm Oil Factory Merbau Fence located in the village of Pagar Merbau III, Lubuk Pakam District, Deli Serdang Regency, North 
Sumatra, Indonesia. The study was conducted from 1 February to 29 February 2016. Next, the study used the Block Diagram of Research as can be seen in Figure 2.

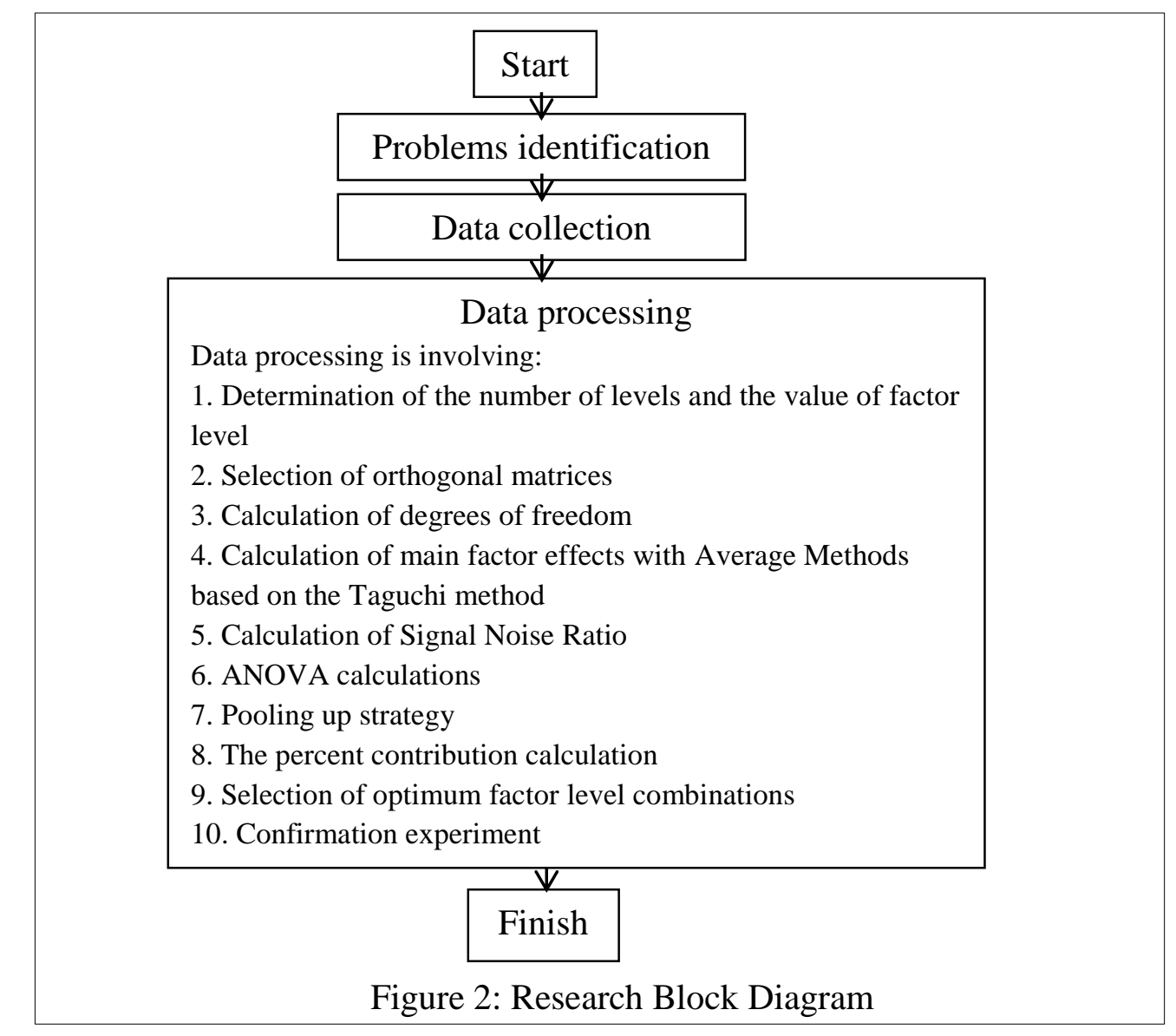

\section{FINDINGS:}

\subsection{Data collection}

The data collected is experimental data with combination of Orthogonal Array $\mathrm{L}_{4}\left(2^{3}\right)$. Data which are collected from the observation of CPO production in February 2016 can be seen in the tables below.

Table 2: Experiment Results for FFA content

\begin{tabular}{|c|c|c|c|c|c|}
\hline \multirow{2}{*}{ No } & \multirow{2}{*}{ Date } & \multirow{2}{*}{ Total Samples } & \multicolumn{2}{|c|}{ FFA content } & \multirow{2}{*}{ Proportion of Disabilities } \\
\cline { 4 - 5 } & & & Accept & Reject & \\
\hline 1 & $15-$ Feb-16 & 12 & 9 & 3 & 0,250 \\
\hline 2 & 16 -Feb-16 & 12 & 8 & 4 & 0,333 \\
\hline 3 & $17-F e b-16$ & 12 & 6 & 6 & 0,500 \\
\hline 4 & $18-F e b-16$ & 12 & 8 & 4 & 0,333 \\
\hline Total & & 48 & 31 & 17 & 1,417 \\
\hline Mean & & & & & 0,354 \\
\hline
\end{tabular}

Table 3: Experiment Results for M content

\begin{tabular}{|c|c|c|c|c|c|}
\hline \multirow{2}{*}{ No } & \multirow{2}{*}{ Date } & \multirow{2}{*}{ Total Samples } & \multicolumn{2}{|c|}{ M content } & \multirow{2}{*}{ Proportion of Disabilities } \\
\cline { 4 - 5 } & & & Accept & Reject & \\
\hline 1 & $15-F e b-16$ & 12 & 10 & 2 & 0,167 \\
\hline 2 & $16-$ Feb-16 & 12 & 7 & 5 & 0,417 \\
\hline 3 & $17-F e b-16$ & 12 & 8 & 4 & 0,333 \\
\hline 4 & $18-F e b-16$ & 12 & 10 & 2 & 0,167 \\
\hline Total & & 48 & 35 & 13 & 1,083 \\
\hline Mean & & & & & 0,271 \\
\hline
\end{tabular}


Table 4: Experiment Results for Level of I

\begin{tabular}{|c|c|c|c|c|c|}
\hline \multirow{2}{*}{ No } & \multirow{2}{*}{ Date } & \multirow{2}{*}{ Total Samples } & \multicolumn{2}{|c|}{ M content } & \multirow{2}{*}{ Proportion of Disabilities } \\
\cline { 4 - 5 } & & & Accept & Reject & 0,167 \\
\hline 1 & $15-$ Feb-16 & 12 & 10 & 2 & 0,167 \\
\hline 2 & $16-$ Feb-16 & 12 & 10 & 2 & 0,167 \\
\hline 3 & $17-F e b-16$ & 12 & 10 & 2 & 0,250 \\
\hline 4 & $18-F e b-16$ & 12 & 9 & 3 & 0,750 \\
\hline Total & & 48 & 39 & 9 & 0,188 \\
\hline Mean & & & & & $27.08 \%$. \\
\hline
\end{tabular}

Based on the data above, it can be seen that the whole total proportion of defects is $27.08 \%$.

\subsection{Determination of the number of levels and the value of factor level}

Determination of this level is following to these considerations:

a. The value of each level is within the range set by the company.

b. This level can still be handled by the existing process technology.

Data on the determination of this level can be seen in Table 5.

Table 5: Determination of the Number and Value of Factor Level

\begin{tabular}{|l|c|c|c|}
\hline \multicolumn{1}{|c|}{ Factor } & Level 1 & Level 2 & Units \\
\hline Boiling temperature & 2,8 & 3 & $\mathrm{~kg} / \mathrm{cm}^{2}$ \\
\hline Pressure on boiling & 120 & 135 & ${ }^{\circ} \mathrm{C}$ \\
\hline Temperature in the clarification unit & 85 & 95 & ${ }^{\circ} \mathrm{C}$ \\
\hline
\end{tabular}

\subsection{Calculation of degrees of freedom}

The degree of freedom calculation is performed to calculate the minimum number of experiments to be performed to investigate the observed factor. The calculation of the degree of freedom and the proposed combination will later affect the selection in the orthogonal matrix table. From the result of factor selection and determination of the number of levels, the degrees of freedom can be calculated are:

Dof for factor $\mathrm{A}=\mathrm{nA}-1=2-1=1$

Dof for factorB $=\mathrm{nB}-1=2-1=1$

Dof for factorC $=\mathrm{nC}-1=2-1=1$

Total Dof $=\left(\mathrm{n}_{\mathrm{A}}-1\right)+\left(\mathrm{n}_{\mathrm{B}}-1\right)+\left(\mathrm{n}_{\mathrm{C}}-1\right)=1+1+1=3$

Based on Dof value, the selection of the OA matrix must satisfy the equation:

Thus :

$$
\mathrm{f}_{\mathrm{LN}} \geq \mathrm{f}
$$

$$
\begin{gathered}
\text { Total Trial }-1 \geq \text { Total Dof } \\
4-1 \geq 3 \\
3 \geq 3
\end{gathered}
$$

The selection of OA types must be based on predetermined conditions as seen in the Table 6 .

Table 6: Selection of OA matrix based on the corresponding Total Dof

\begin{tabular}{|c|c|}
\hline Total Dof & Orthogonal Array (OA) \\
\hline $2-3$ & $\mathrm{~L}_{4}\left(2^{3}\right)$ \\
\hline $4-7$ & $\mathrm{~L}_{8}\left(2^{7}\right)$ \\
\hline $8-11$ & $\mathrm{~L}_{12}\left(2^{11}\right)$ \\
\hline $12-15$ & $\mathrm{~L}_{16}\left(2^{15}\right)$ \\
\hline
\end{tabular}

Based on the number of degrees of freedom above, the corresponding OA matrix is the Orthogonal Array $\mathrm{L}_{4}\left(2^{3}\right)$.

Where : 
$\mathrm{L}=$ rectilinear latin design.

$4=$ number of rows or experiments.

$2=$ number of levels.

$3=$ number of columns or factors.

Then, composition of Orthogonal Array $\mathrm{L}_{4}\left(2^{3}\right)$ is illustrated in Table 7.

Table 7: Composition of Orthogonal Array $\mathrm{L}_{4}\left(2^{3}\right)$

\begin{tabular}{|c|c|c|c|}
\hline & \multicolumn{3}{|c|}{ Factor } \\
\hline \multirow{2}{*}{ Trial } & A & B & C \\
\cline { 2 - 4 } & \multicolumn{3}{|c|}{ Column Number } \\
\cline { 2 - 4 } & 1 & 2 & 3 \\
\hline 1 & 1 & 1 & 1 \\
\hline 2 & 1 & 2 & 2 \\
\hline 3 & 2 & 1 & 1 \\
\hline 4 & 2 & 2 & \\
\hline
\end{tabular}

There are 3 factors which used in this experiment, namely: Factor A (boiling pressure) is placed in column 1 , factor B (boiling temperature) is placed in column 2 and factor C (temperature of clarification unit) is placed in column 3.

\subsection{Calculation of main factor effects with Average Methods based on the Taguchi method}

The experimental results were obtained by setting machine related to the three factors previously made in accordance with the matrix of factor level combinations. From experiment, the results are grouped by accept and reject category. Thus the results are recorded and can be seen in the Table 8 .

Table 8: Experimental result of Free Fatty Acid (FFA) level.

\begin{tabular}{|c|c|c|c|c|c|}
\hline \multirow{2}{*}{ Trial } & \multicolumn{3}{|c|}{ Factor } & \multirow{2}{*}{ Accept } & \multirow{2}{*}{ Reject } \\
\cline { 2 - 5 } & A & B & C & & 3 \\
\hline 1 & 1 & 1 & 1 & 9 & 4 \\
\hline 2 & 1 & 2 & 2 & 8 & 6 \\
\hline 3 & 2 & 1 & 2 & 6 & 4 \\
\hline 4 & 2 & 2 & 1 & 8 & 4 \\
\hline
\end{tabular}

\subsection{Calculation of Signal Noise Ratio}

a. Average Method Calculation.

The result of Average Method calculation for each factor level can be seen in the Table 9 .

Table 9: Factor rating based on Average.

\begin{tabular}{|c|c|c|c|c|}
\hline \multirow{2}{*}{ Factor } & \multicolumn{2}{|c|}{ Level } & \multirow{2}{*}{ Differences } & \multirow{2}{*}{ Ranking } \\
\cline { 2 - 3 } & 1 & 2 & & 1 \\
\hline $\mathbf{A}$ & 3,5 & 5 & 1,5 & 3 \\
\hline $\mathbf{B}$ & 4,5 & 4 & 0,5 & 2 \\
\hline
\end{tabular}

b. S/N Ratio Calculation.

The result of $S / N$ Ratio factor ranking calculation can be seen in the Table 10.

Table 10: S/N Ratio rank.

\begin{tabular}{|c|c|c|c|c|}
\hline \multirow{2}{*}{ Factor } & \multicolumn{2}{|c|}{ Level } & \multirow{2}{*}{ Differences } & \multirow{2}{*}{ Ranking } \\
\cline { 2 - 3 } & 1 & 2 & & 1 \\
\hline A & $-21,583$ & $-27,601$ & 6,081 & 3 \\
\hline B & $-25,102$ & $-24,082$ & 1,02 & 2 \\
\hline C & $-21,583$ & $-27,601$ & 6,018 & \\
\hline
\end{tabular}




\subsection{ANOVA calculations}

In the ANOVA calculations below, the product is categorized into reject class and accepts class as it focuses on the defective category of Smaller the Better. For the calculation of ANOVA will be used the formulas as follows:

1. Average overall experiment.

$$
\bar{Y}=\frac{\sum Y}{n}
$$

2. Total number of squares.

$$
S_{T}=\sum Y^{2}
$$

3. The sum of squares due to the average

$$
S_{m}=n \bar{Y}^{2}
$$

4. The sum of squares due to factors.

$$
\begin{aligned}
& S_{A}=\frac{(\text { Total } A 1)^{2}}{n A 1}+\frac{(\text { Total } A 2)^{2}}{n A 2}-S_{m} \\
& S_{B}=\frac{(\text { Total } B 1)^{2}}{n B 1}+\frac{(\text { Total } B 2)^{2}}{n B 2}-S_{m} \\
& S_{C}=\frac{(\text { Total } C 1)^{2}}{n C 1}+\frac{(\text { Total } C 2)^{2}}{n C 2}-S_{m}
\end{aligned}
$$

5. The sum of squares by error.

6. Calculation of degrees of freedom for each factor.

$$
S_{e}=S_{T}-S_{A}-S_{B}-S_{C}
$$

$$
\mathrm{V}_{\mathrm{A}}=(\text { Total Class }-1) \mathrm{x}(\text { Total Level }-1)
$$

For the other factor is calculated with same method:

$$
\begin{aligned}
& V_{A}=V_{B}=V_{C}=1 \\
& V_{e}=V_{T}-V_{A}-V_{B}-V_{C}
\end{aligned}
$$

7. Average number of squares.

The mean of squares is calculated from the division of the sum of squares by degrees of freedom.

8. F-ratio calculation.

$$
\begin{array}{ll}
M S_{A}=\frac{S S_{A}}{V_{A}} & M S_{B}=\frac{S S_{B}}{V_{B}} \\
M S_{A}=\frac{S S_{C}}{V_{C}} & M S_{e}=\frac{S S_{e}}{V_{e}}
\end{array}
$$

$$
F_{A}=\frac{M S_{A}}{M S_{e}} \quad F_{B}=\frac{M S_{B}}{M S_{e}} \quad F_{C}=\frac{M S_{C}}{M S_{e}}
$$


Table 11: The result of Factor Variance Analysis

\begin{tabular}{|c|c|c|c|c|}
\hline Factor & SS & V & MS & F-count \\
\hline A & 2,25 & 1 & 2,25 & 1,37 \\
\hline B & 0,25 & 1 & 0,25 & 0,15 \\
\hline C & 2,25 & 1 & 2,25 & 1,37 \\
\hline Error & 72,25 & 44 & 1,64 & 1 \\
\hline St & 77 & 47 & - & - \\
\hline
\end{tabular}

\subsection{Pooling up strategy}

A pooling-up strategy is undertaken to determine which factors have the most significant effect on product quality. Pooling-up is conducted through calculations and ANOVA tables divided the two stages of partial pooling I $\left(\mathrm{M}_{\text {Scount }} \leq \mathrm{M}_{\text {Serror }}\right)$ and partial pooling II $\left(\mathrm{F}_{\text {count }} \leq \mathrm{F}_{\text {table }}\right)$.

1. Partial Pooling I

In this stage, the factors are determined with the provisions of the value: $\left(\mathrm{M}_{\text {scount }} \leq \mathrm{M}_{\text {Serror }}\right)$

Table 12: The result of Partial Pooling I

\begin{tabular}{|c|c|c|c|c|c|c|}
\hline Factor & Pooled & SS & V & MS & F-count & SS' \\
\hline A & - & 2,25 & 1 & 2,25 & 1,398 & 0,64 \\
\hline B & Yes & - & - & - & - & - \\
\hline C & - & 2,25 & 1 & 2,25 & 1,398 & 0,64 \\
\hline Error & - & 72,50 & 45 & 1,61 & - & 75,72 \\
\hline St & - & 77 & 47 & - & - & 77 \\
\hline
\end{tabular}

2. Partial Pooling II

This stage is conducted through $\left(\mathrm{F}_{\text {count }} \leq \mathrm{F}_{\text {table }}\right)$ with $95 \%$ of confidence level.

Table 13: The result of Partial Pooling II

\begin{tabular}{|c|c|c|c|c|c|c|}
\hline Factor & Pooled & SS & V & MS & F-count & SS' \\
\hline A & Yes & - & - & - & - & - \\
\hline B & - & 0,25 & 1 & 0,25 & 0,152 & $-1,39$ \\
\hline C & Yes & - & - & - & - & - \\
\hline Error & - & 77 & 47 & 1,64 & 1 & 78,39 \\
\hline St & - & 77,25 & 48 & - & - & 77 \\
\hline
\end{tabular}

Based on Partial Pooling I and II, it can be seen that the most influential factor on FFA level are A and C, namely boiling pressure and temperature of clarification unit.

\subsection{Selection of optimum factor level and the percent contribution calculation}

The percentage contribution of each factor is calculated by the formula:

Then, the contribution of each factor are:

$$
\rho=\frac{S S_{\text {factor }}}{S_{T}} \cdot 100 \%
$$

$$
\begin{aligned}
& \rho_{A}=\frac{2.25}{77.25} \cdot 100 \%=2.91 \% \\
& \rho_{B}=\frac{0.25}{77.25} \cdot 100 \%=0.32 \%
\end{aligned}
$$




$$
\rho_{C}=\frac{2.25}{77.25} \cdot 100 \%=2.91 \%
$$

Factors influencing the most optimum FFA levels have been determined by factor A level 1 (boiling pressure $2,8 \mathrm{~kg} / \mathrm{cm}^{2}$ ), C level 1 (clarification unit temperature $85{ }^{\circ} \mathrm{C}$ ) and $\mathrm{B}$ level 2 factor (boiling temperature 135 $\left.{ }^{\circ} \mathrm{C}\right)$.

\section{8. combinations}

\subsection{Confirmation experiment}

The results of the confirmation experiment can be seen in the Table 14.

Table 14: Confirmation experimental results for FFA levels

\begin{tabular}{|c|c|c|c|c|}
\hline \multirow{2}{*}{ No } & \multirow{2}{*}{ Total Sample } & \multicolumn{2}{|c|}{ FFA Level } & Defects \\
\cline { 2 - 4 } & 12 & Accept & Reject & 0,250 \\
\hline 1 & 12 & 9 & 3 & 0,167 \\
\hline 2 & 12 & 9 & 2 & 0,250 \\
\hline 3 & 12 & 9 & 3 & 0,250 \\
\hline 4 & & 3 & 0.917 \\
\hline \multicolumn{2}{|c|}{ Total } & & & 0.229 \\
\hline
\end{tabular}

Based on the Table 14, it can be seen that the total proportion of defects overall after the optimal combination of settings applied based on research with Taguchi method is $16.67 \%$. After applying the optimal combination of settings based on the Taguchi method, the overall proportion of overall defects decreased by $10.42 \%$.

\section{CONCLUSION:}

By using Taguchi method in quality improvement effort at PT. Perkebunan Nusantara II PKS Pagar Merbau, it can be concluded that combination of optimal level setting based on Taguchi method is on FFA levels: the factor of boiling pressure $2,8 \mathrm{~kg} / \mathrm{cm}^{2}$, the factor of clarification unit temperature at level $1,85^{\circ} \mathrm{C}$ and factor of boiling temperature at level $2,135^{\circ} \mathrm{C}$.

\section{REFERENCES:}

1. A. H. Lubis, "ICT Usage Amongst Lecturers and Its Impact Towards Learning Process Quality," vol. 34, no. 1, pp. 284-299, 2018.

2. S. Aryza, M. Irwanto, Z. Lubis, A. P. U. Siahaan, R. Rahim, and M. Furqan, "A Novelty Design of Minimization of Electrical Losses in A Vector Controlled Induction Machine Drive," IOP Conf. Ser. Mater. Sci. Eng., vol. 300, no. 1, 2018.

3. R. Ginting, "Sistem Produksi”. Graha Ilmu, Yogyakarta, 2007.

4. Soejanto, "Desain Eksperimen Dengan Metode Taguchi", Edisi Pertama, Graha Ilmu, Yogyakarta, 2009.

5. Sugiyono. "Metode Penelitian Manajemen, Cetakan Ketiga, Alfabeta, Bandung, 2013.

6. D. H. Besterfield, Quality Control, Fifth Edition, Prentice-Hall International, Inc., Englewood Cliffs, New Jersey, 1994.

7. Ernawati, Aplikasi Metode Taguchi Dalam Pengendalian Kualitas Produksi, Jurnal Teknosains Fakultas Teknologi Dan Sains, Vol. 8 No. 2, UIN Alauddin Makasar, 2014. 